\title{
Peranan Infrastruktur terhadap Pertumbuhan Ekonomi dan Implikasi pada Kebijakan Pembangunan di Kota Samarinda
}

\author{
1) WARSILAN, 2) AKHMAD NOOR
}

\author{
Fakultas Ekonomi, Universitas Mulawarman Samarinda \\ email: warsilan_moch@yahoo.com akhmadnoor@yahoo.com
}

\begin{abstract}
Infrastructure plays a role in economic growth. This study describes the relationship of economic growth and infrastructure, analyze the impact of infrastructure on economic growth and analyze the policy implications of road construction in the Samarinda city. The results obtained show that the health center infrastructure, clean water and roads have a positive and significant impact on economic growth. Results showed that the method AHP first priority goal is to increase employment by increasing the length target priority roads, the second priority boost economic growth with the addition of roads, and the third priority of reducing poverty with the addition of road length.
\end{abstract}

Keywords: infrastructure, economic growth, AHP.

\begin{abstract}
Abstrak. Infrastruktur berperan dalam pertumbuhan ekonomi. Penelitian ini menggambarkan hubungan pertumbuhan ekonomi dan infrastruktur, menganalisis pengaruh infrastruktur terhadap pertumbuhan ekonomi dan menganalisis implikasi kebijakan pembangunan jalan di Kota Samarinda. Hasil yang diperoleh menunjukkan bahwa infrastruktur puskesmas, air bersih dan jalan memiliki pengaruh positif dan signifikan pada pertumbuhan ekonomi. Hasil dengan metode AHP menunjukan bahwa proritas sasaran pertama ialah meningkatkan penyerapan tenaga kerja dengan prioritas sasarannya penambahan panjang jalan, prioritas kedua meningkatkan pertumbuhan ekonomi dengan penambahan fasilitas jalan dan prioritas ketiga mengurangi kemiskinan dengan penambahan panjang jalan.
\end{abstract}

Kata-kata Kunci: infrastruktur, pertumbuhan ekonomi, AHP.

\section{Pendahuluan}

Pembangunan merupakan suatu kenyataan fisik sekaligus tekad masyarakat untuk berupaya sekeras mungkin melalui serangkaian kombinasi proses sosial, ekonomi, dan institusional demi mencapai kehidupan yang serba lebih baik. Proses pembangunan memiliki tiga tujuan yaitu peningkatan ketersediaan serta perluasan distribusi berbagai macam barang kebutuhan hidup yang pokok, peningkatan standar hidup dan perluasan pilihan-pilihan ekonomis dan sosial bagi setiap individu serta bangsa secara keseluruhan (Todaro dan Smith, 2006).

Pembangunan infrastruktur akan dapat berdampak pada pertumbuhan ekonomi, baik secara langsung maupun tidak langsung.
Infrastruktur sendiri merupakan prasyarat bagi sektor-sektor lain untuk berkembang dan juga sebagai sarana penciptaan hubungan antara satu dengan yang lainnya. Pemberdayaan sumber daya untuk membangun infrastruktur akan memicu proses ekonomi sehingga menimbulkan penggandaan dampak ekonomi maupun sosial (Setiadi, 2006).

Perkembangan daerah perkotaan lebih pesat dibandingkan di pedesaan. Samarinda telah mengalami perkembangan dan berkaitan dengan daerah sekitarnya seperti Bontang, Tenggarong, dan Balikpapan. Oleh karena itu, tidak dapat dipisahkan perkembangannya sebagai daerah penyangga bagi Kota Samarinda.

Struktur perekonomian Kota Samarinda

Received: 13 Juni 2015, Revision: 4 September 2015, Accepted: 22 Desember 2015

Print ISSN: 0215-8175; Online ISSN: 2303-2499. Copyright@2015. Published by Pusat Penerbitan Universitas (P2U) LPPM Unisba Terakreditasi SK Kemendikbud, No.040/P/2014, berlaku 18-02-2014 s.d 18-02-2019 
yang digambarkan oleh distribusi Produk Domestik Regional Bruto (PDRB) atas dasar harga berlaku menunjukan bahwa kontribusi nilai tertinggi PDRB Kota Samarinda pada tahun 2012 dicapai oleh sektor perdagangan, hotel, dan restoran yaitu selalu berada diatas 30 persen. Hal tersebut dapat dilihat di beberapa kecamatan di Kota Samarinda seperti Samarinda Ilir, Samarinda Ulu, Samarinda Kota, Palaran, dan lain-lain.

Kota Samarinda merupakan daerah ibu kota di Kalimantan Timur dengan sekitar 718 $\mathrm{Km}^{2}$. Kota Samarinda memiliki 10 kecamatan dengan jumlah penduduk sekitar 781.184 jiwa pada tahun 2012. PDRB Kota Samarinda urutan kelima setelah Kota Balikpapan sebesar 35.861.673 juta rupiah (BPS, 2013). Dengan jumlah penduduk tertinggi di Kalimantan Timur, Kota Samarinda diharapkan dapat meningkatkan pembangunan infrastruktur untuk menunjang kegiatan yang berlangsung di Kota Samarinda.

Infrastruktur yang memadai sebagai penunjang aktivitas ekonomi akan berdampak pada pertumbuhan ekonomi. Infrastruktur jalan dalam kondisi baik akan mempermudah mobilisasi penyaluran barang dan jasa dan dapat mengurangi akses masyarakat yang terisolasi. Infrastruktur air bersih dapat meningkatkan output yang dihasilkan. Infrastruktur puskesmas akan meningkatkan produktivitas pekerja.Pertumbuhan infrastruktur di Kota Samarinda menunjukkan pertumbuhan yang positif.

Pada 2012, jalan mengalami pertumbuhan positif, hal ini dikarenakan terjadi penambahan jumlah panjang jalan dalam kondisi baik. Apabila semakin banyak jalan yang rusak akan menurunnya efisiensi jalan. Pertumbuhan infrastruktur air bersih dan puskesmas pada 2010 sampai 2012 menunjukkan pertumbuhan yang positif. Hal ini menunjukkan bahwa dari tahun ke tahun kebutuhan akan sumber air bersih dan puskesmas selalu meningkat walaupun pertumbuhan di tiap tahunnya selalu berbeda.

Hal tersebut akan menjadi masalah untuk pertumbuhan ekonomi Kota Samarinda yang terlihat pada nilai PDRB di Kota Samarinda apabila infrastruktur kurang dan tidak memadai. Dari uraian tersebut yang telah disampaikan, maka perlunya penelitian terkait dengan infrastruktur dan pertumbuhan ekonomi, terutama di Kota Samarinda. Berdasarkan uraian yang telah dijelaskan maka permasalahan pokok yang akan di angkat dalam tulisan ini, yaitu: bagaimana perkembangan PDRB dan infrastruktur (puskesmas, air bersih dan jalan) di Kota Samarinda dan Bagaimana pengaruh infrastruktur (puskesmas, air bersih dan jalan) terhadap pertumbuhan ekonomi di Kota Samarinda.

\section{Pertumbuhan Ekonomi}

Secara umum, pertumbuhan ekonomi didefinisikan sebagai peningkatan dalam kemampuan dari suatu perekonomian dalam memproduksi barang dan jasa. Dapat dikatakan bahwa pertumbuhan ekonomi lebih menunjuk pada perubahan yang kuantitatif (quantitative change) dan biasanya diukur dengan menggunakan data Produk Domestik Regional Bruto (PDRB), atau pendapatan atau output per kapita.

Menurut Badan Pusat Statistik (2013:1)

PDRB merupakan jumlah nilai tambah dan jumlah nilai barang dan jasa akhir yang dihasilkan oleh seluruh unit usaha di suatu daerah dalam suatu periode tertentu. PDRB atas harga berlaku menggambarkan nilai tambah barang dan jasa yang dihitung menggunakan harga pada tahun tertentu sebagai dasar. PDRB atas dasar harga berlaku digunakan untuk melihat pergeseran dan struktur ekonomi, sedang PDRB atas dasar harga konstan digunakan untuk mengetahui pertumbuhan ekonomi dari tahun ke tahun

Todaro dan Smith (2006) menjelaskan bahwa pertumbuhan ekonomi merupakan suatu proses peningkatan kapasitas produksi dalam suatu perekonomian secara terus menerus atau berkesinambungan sepanjang waktu sehingga menghasilkan tingkat pendapatan dan output nasional yang semakin lama semakin besar.

Ada tiga komponen utama dalam menentukan pertumbuhan ekonomi setiap bangsa, yaitu: Akumulasi modal, meliputi semua bentuk investasi baru yang ditanamkan seperti tanah, peralatan fisik, serta sumber daya manusia melalui perbaikan di bidang kesehatan, pendidikan, dan keterampilan; Pertumbuhan jumlah penduduk, yang pada akhirnya menyebabkan pertumbuhan angkatan kerja; dan Kemajuan teknologi, yang diartikan sebagai cara untuk menyelesaikan pekerjaan.

Akumulasi modal diperoleh bila sebagian dari pendapatan yang diterima saat ini ditabung dan diinvestasikan kembali dengan tujuan meningkatkan output dan pendapatan di masa yang akan datang. Pengadaan pabrikpabrik, mesin mesin, peralatan dan bahan baku akan meningkatkan stock modal (capital stock) fisik suatu negara dan memungkinkan 
untuk meningkatkan tingkat output yang ingin dicapai. Investasi produktif yang bersifat langsung tersebut harus ditopang oleh berbagai investasi penunjang yang disebut dengan investasi infrastruktur sosial dan ekonomi. Pengadaan infrastruktur ini meliputi pembangunan jalan, penyediaan energi listrik, penyediaan sarana air bersih, perbaikan sanitasi, pembangunan fasilitas komunikasi, dan sebagainya. Keseluruhan dari adanya penyediaan infrastruktur ini sangat dibutuhkan dalam menunjang dan mengintegrasikan aktivitas-aktivitas ekonomi dalam suatu Negara.

\section{Infrastruktur}

Infrastruktur merujuk pada sistem fisik yang menyediakan transportasi, pengairan, drainase, bangunan-bangunan gedung dan fasilitas publik yang lain yang dibutuhkan untuk memenuhi kebutuhan dasar manusia dalam lingkup sosial dan ekonomi. Sistem infrastruktur merupakan pendukung utama fungsi-fungsi sistem sosial dan ekonomi dalam kehidupan sehari-hari masyarakat. Sistem infrastruktur dapat didefinisikan sebagai fasilitas-fasilitas atau strukturstruktur dasar, peralatan-peralatan, instalasiinstalasi yang dibangun dan yang dibutuhkan untuk berfungsinya sistem sosial dan sistem ekonomi masyarakat.

Infrastruktur dalam ilmu ekonomi merupakan wujud dari public capital (modal publik) dibentuk dari investasi yang dilakukan oleh pemerintah yang meliputi: jalan, jembatan, dan sistem saluran pembuangan (Mankiw, 2001:38). Hal ini menunjukkan bahwa infrastruktur cenderung mengarah pada pembahasan barang publik seperti yang dijelaskan oleh Stiglizt (2000:104) yang mengatakan bahwa beberapa infrastruktur jalan merupakan salah satu barang publik yang disediakan oleh pemerintah.

World Bank (1994:12) membagi infrastruktur atas tiga bagian, yaitu: (1) Infrastruktur ekonomi merupakan pembangunan fisik yang menunjang aktivitas ekonomi: public utilities (tenaga listrik, telkom, air, sanitasi, gas), pekerjaan umum atau public work (jalan, bendungan, kanal, irigasi, dan drainase), dan sektor transportasi (jalan, rel, pelabuhan, lapangan terbang dan sebagainya). (2) Infrastruktur sosial merupakan infrastruktur yang mengarah pada pembangunan manusia dan lingkungannya seperti pendidikan, kesehatan, perumahan, dan rekreasi. (3) Infrastruktur administrasi merupakan infrastruktur dalam bentuk penegakan hukum, kontrol administrasi dan koordinasi.

Infrastruktur ekonomi biasanya mempunyai karakteristik monopoli alamiah karena pengadaan dan pengoperasian infrastruktur ekonomi akan lebih ekonomis jika hanya oleh satu perusahaan daripada dua atau lebih perusahaan (Taufiq, 2006).

Monopoli alamiah biasanya muncul ketika skala ekonomis yang diperlukan untuk menyediakan suatu barang atau jasa sedemikian besar, sehingga akan lebih bermanfaat. Apabila pasokan barang atau jasa diserahkan kepada satu perusahaan saja (Mankiw, 2001:376). Barang dan jasa yang yang termasuk dalam monopoli alamiah akan menyebabkan intervensi pemerintah yang tinggi dalam penyediaan barang atau jasa tersebut. Peran dan intervensi pemerintah dalam hal infrastruktur baik secara langsung dengan pengadaan barang dan jasa infrastruktur, maupun secara tidak langsung dengan peraturan-peraturan pemerintah di bidang infrastruktur yang dikeluarkan, sangat diperlukan dalam mendukung pertumbuhan ekonomi dalam lingkup nasional maupun regional.

Kebijakan pemerintah sebagai bentuk dalam menjalankan fungsi dan peran pemerintah dalam rangka untuk mensejahterakan masyarakat dapat melalui berbagai cara dan model dalam pembangunan. Sebagaimana seperti kebijakan pembangunan pengembangan kawasan (Kamuli, 2014).

\section{Metodologi Penelitian}

Penelitian ini termasuk dalam penelitian eksplanatori, karena menjelaskan hubungan kausal antara variabel dan disertai pengujian hipotesis. Dalam penelitian ini menggunakan sensus, dengan pertimbangan populasinya kecil dan masing-masing elemennya berbeda satu dengan lainnya.

Data yang digunakan adalah data skunder yang telah dipublikasikan oleh Badan Pusat Statistik dan Bappeda Samarinda, secara runtut waktu (times series) selama 23 tahun, sejak tahun 1989 sampai dengan tahun 2012.

\section{Alat Analisis Penelitian}

Metode OLS dikemukakan oleh ahli matematika bangsa Jerman yaitu Carl Friedrich Gauss. Metode OLS dengan asumsiasumsi tertentu, mempunyai sifat statistik yang sangat menarik dan menjadikan metode tersebut adalah metode yang baik untuk mengestimasi parameter persamaan regresi (Firdaus, 2004).

Proses Herarki Analitik (Analitic 
Tabel 1

Hasil Estimasi Model Persamaan Pengaruh Infrastruktur terhadap Pertumbuhan Ekonomi di Kota Samarinda

\begin{tabular}{|c|c|c|c|c|c|}
\hline Variable & & Std. Error & & Prob. & VIF \\
\hline & & & & & \\
\hline LnPUS & 0.417844 & 0.186026 & 2.246153 & 0.0361 & 4,108 \\
\hline LnAIR & 0.060952 & 0.026976 & 2.259474 & 0.0352 & 2.387 \\
\hline LnJLN & 0.254260 & 0.054261 & 4.685883 & 0.0001 & 2.994 \\
\hline $\mathrm{C}$ & 10.43857 & 0.550174 & 18.97322 & 0.0000 & \\
\hline R-squared & 0.876332 & Mean dependent var & & 16.97539 & \\
\hline Adjusted R-squared & 0.857782 & S.D. dependent var & & 0.238144 & \\
\hline S.E. of regression & 0.089808 & Akaike info criterion & & -1.831263 & \\
\hline Sum squared resid & 0.161311 & Schwarz criterion & & -1.634920 & \\
\hline Log likelihood & 25.97515 & Hannan-Quinn criter. & & -1.779173 & \\
\hline F-statistic & 47.24127 & Durbin-Watson stat & & 1.029287 & \\
\hline Prob(F-statistic) & 0.000000 & & & & \\
\hline
\end{tabular}

Sumber: Hasil E-Views (Lampiran 2)

Hierarchy Process) dikembangkan oleh Thomas L. Saaty dari Wharton School of Business pada tahun 1970-an. Model yang berada di wilayah probabilistik ini merupakan model pengambilan keputusan dan perencanaan strategis. Ciri khas model ini adalah penentuan skala prioritas atas alternatif pilihan berdasarkan suatu proses analisis secara berjenjang, terstruktur atas variabel keputusan.

\section{Analisis dan Pembahasan Hasil Pe- nelitian}

Pengaruh Infrastruktur terhadap Pertumbuhan Ekonomi. Penelitian ini menggunakan uji kriteria ekonometrik, uji yang pertama yaitu uji kenormalan, uji kenormalan digunakan untuk memeriksa apakah error term menyebar normal atau tidak. Uji normalitas dilakukan dengan Jarque Bera Test. Hasil uji didapat nilai probabilitas $(0.447952)>$ a 5 persen maka error term menyebar normal.

Uji yang kedua ialah uji autokolerasi. Autokolerasi merupakan korelasi yang terjadi antar observasi dalam satu variabel atau korelasi error masa lalu dan error masa sekarang. Pengujian adanya permasalahan dalam pengolahan data autokolerasi dilakukan dengan menggunakan uji Breusch-Godfreg Serial Correlation Test dengan hasil didapat pada Prob-Chi Squared sebesar $0.0516>$ a 5 persen, sehingga pada persamaan ini tidak terapat gejala autokolerasi.

Uji yang ketiga ialah uji heteroskedastisitas, uji ini merupakan gejala yang terjadi dalam model regresi linier jika variabelnya berbeda-beda atau bervariasi. Pengujian masalah heteroskedastisitas dilakukan dengan menggunakan White Test. Hasil uji heteroskedastisitas menunjukkan bahwa persamaan fungsi pada penelitian ini tidak mengandung gejala heteroskedastisitas. Pada persamaan didapat nilai Prob ChiSquare sebesar $0.8627>$ a 5 persen. Dengan nilai hasil tersebut dengan asumsi tidak ada heteroskedastisitas terpenuhi.

Uji keempat ialah uji multikolinieritas, asumsi ini menyatakan bahwa tidak adanya keterkaitan atau hubungan linier antar variabel bebas penyusun model. Jika ada hubungan linier antara dua atau lebih variabel bebas maka dikatakan terjadi multikolinieritas dan hal tersebut merupakan penyimpangan asumsi. Untuk mengetahui ada atau tidaknya multikolinieritas, maka dapat dilakukan dengan VIF $<10$ karena semua variabel pada Tabel 3 VIF $<10$ maka uji multikolinieritas terpenuhi.

Persamaaan regresi untuk analisis pengaruh infrastruktur terhadap pertumbuhan ekonomi Kota Samarinda adalah sebagai berikut:

LnPDRB $=10.43857+0.41784$ LnPUS $+0.06095 \mathrm{LnAIR}+0.25426$ LnJLN 
Berdasarkan Tabel 4.1 terlihat bahwa hasil estimasi yang dihasilkan dari analisis pengaruh infrastruktur terhadap pertumbuhan ekonomi di Kota Samarinda adalah nilai koefisien determinasi $R$-Square adalah 0.876332 persen. Artinya 0.876332 persen keragaman variabel dependen adalah PDRB dapat dijelaskan oleh model yaitu jalan, listrik, air bersih dan puskesmas; sedangkan sisanya 0.123668 persen keragaman tidak dapat dijelaskan oleh regresi yang digunakan.

Nilai probabilitas F-statistik yang dihasilkan adalah sebesar 0,000000 yang artinya variabel-variabel independen dalam penelitian ini berpengaruh terhadap variabel dependen pada taraf nyata lima persen. Maka dengan tingkat selang kepercayaan 95 persen, dapat disimpulkan bahwa variabel puskesmas, air bersih dan jalan bersamasama signifikan terhadap PDRB dengan tingkat kepercayaan 95 persen.

Berdasarkan hasil yang diperoleh, menunjukkan bahwa nilai probabilitas dari variabel puskesmas, air bersih dan jalan lebih kecil dari taraf nyata lima persen masingmasing $0.0001,0.0352$, dan 0.0361 . Hal ini dapat dikatakan bahwa variabel independen tersebut secara individu berpengaruh signifikan terhadap pertumbuhan ekonomi Kota Samarinda yang ditunjukkan oleh nilai PDRB.

Berdasarkan hasil estimasi yang diperoleh pada Tabel 4.1, panjang jalan berpengaruh positif terhadap pertumbuhan ekonomi di Kota

Samarinda. Nilai koefisien variabel infrastruktur jalan sebesar 0.254260 artinya pertambahan panjang jalan sebesar satu persen akan meningkatkan pertumbuhan ekonomi Kota Samarinda sebesar 0.254260 persen (cateris paribus). Hal ini sesuai dengan hipotesis awal yang menyebutkan bahwa pertumbuhan infrastruktur jalan akan meningkatkan pertumbuhan ekonomi di Kota Samarinda.

Panjang jalan mempunyai peran yang penting dalam kegiatan perekonomian daerah. Adanya fasilitas infrastruktur jalan akan mempermudah distribusi faktor produksi, baik barang maupun jasa. Selain itu pengembangan jalan akan membuka akses suatu wilayah terhadap wilayah lainnya sehingga pertumbuhan ekonomi akan meningkat dan mengurangi daerah yang terisolasi. Kondisi jalan yang digunakan dalam penelitian ini adalah jalan dengan kondisi baik.

Jumlah air bersih yang tersalurkan ke masyarakat memiliki pengaruh yang positif terhadap pertumbuhan ekonomi Kota Samarinda. Nilai koefisien dari infrastruktur air bersih ini adalah sebesar 0,060952. Artinya kenaikan jumlah air bersih yang tersalurkan sebesar satu persen akan meningkatkan pertumbuhan ekonomi Kota Samarinda sebesar 0,060952 persen (cateris paribus). Hal ini sesuai dengan hipotesis awal yang menyatakan bahwa bertambahnya jumlah air bersih yang tersalurkan akan meningkatkan pertumbuhan ekonomi di Kota Samarinda.

Jumlah air yang tersalurkan menunjukkan seberapa besar jumlah air bersih yang dikonsumsi oleh masyarakat. Semakin banyak jumlah air bersih yang digunakan menggambarkan seberapa besar akses suatu daerah terhadap ketersediaan air bersih. Air bersih yang digunakan dalam penelitian ini yaitu air bersih yang disalurkan oleh PDAM di Kota Samarinda.

Jumlah puskesmas memiliki pengaruh yang positif terhadap pertumbuhan ekonomi Kota Samarinda. Nilai koefisien dari infrastruktur puskesmas ini adalah sebesar 0,417844 . Artinya, kenaikan jumlah air bersih yang tersalurkan sebesar satu persen akan meningkatkan pertumbuhan ekonomi Kota Samarinda sebesar 0,417844 persen (cateris paribus). Hal ini sesuai dengan hipotesis awal yang menyatakan bahwa bertambahnya jumlah puskesmas yang ada akan meningkatkan pertumbuhan ekonomi di Kota Samarinda.

Jumlah puskesmas yang ada menunjukkan seberapa besar masyarakat menggunakan puskesmas tersebut. Semakin banyak jumlah puskesmas yang digunakan menggambarkan seberapa besar akses suatu daerah terhadap puskesmas. Puskesmas yang digunakan dalam penelitian ini yaitu puskesmas, puskesmas pembantu dan puskesmas keliling.

\section{Prioritas Kebijakan Pembangunan Jalan di Kota Samarinda dengan Metode AHP}

Penyusunan herarki merupakan bagian terpenting dari model AHP, karena menjadi dasar para narasumber untuk memberi penilaian/ pendapat secara lebih sederhana. Dalam penelitian ini, peneliti memberikan kuesioner kepada orang yang benar-benar ahli dibidangnya. Dalam penelitian ini 
peneliti memberikan kuesioner kepada BAPPEDA Kota Samarinda yang berdasar pada Rancangan Pembangunan Jangka Menengah Daerah (RPJMD) Kota Samarinda, diharapkan permasalahan yang kompleks akan menjadi lebih sederhana dan mudah untuk dipahami. Dalam model AHP yang digunakan dalam penelitian ini, herarki yang disusun terdiri atas 3 level, dengan level puncak sebagai fokus/ goal dari herarki, yaitu: "Strategi Kebijakan Pembangunan pada Pembangunan Jalan". Herarki model AHP secara lengkap disajikan dalam metode penelitian.

Level 1 adalah Sasaran, yang terbagi menjadi tiga sasaran yang hendak dicapai, yaitu: (1) Sasaran mengurangi kemiskinan adalah suatu sasaran yang bermaksud untuk mengurangi kemiskinan yang merupakan masih menjadi masalah utama bagi Pemerintah Daerah Kota Samarinda. (2) Sasaran meningkatkan pertumbuhan ekonomi, adalah suatu sasaran yang bermaksud untuk menciptakan upaya dalam meningkatkan pertumbuhan ekonomi, dalam hal ini dilihat PDRB Kota Samarinda. (3) Sasaran meningkatkan penyerapan tenaga kerja, adalah suatu sasaran yang bermaksud untuk mengurangi pengangguran di Kota Samarinda.

Level 2 adalah Alternatif strategi kebijakan pembangunan jalan di Kota Samarinda, yaitu: (1) Meningkatkan perbaikan jalan; alternatif ini bermaksud untuk meningkatkan perbaikan jalan yang yang berada di Kota Samarinda, seperti memperbaiki jalan yang rusak yang berada di setiap daerah di Kota Samarinda. (2) Meningkatkan panjang jalan; alternatif ini bermaksud untuk meningkatkan panjang jalan ke daerah-daerah yang belum adanya jalan dan ke daerah yang hanya biasa dilewati oleh kendaraan beroda dua saja. (3) Meningkatkan fasilitas jalan; alternatif ini bermaksud untuk meningkatkan fasilitas utilitas jalan seperti drainase, rambu, marka, pengaman jalan yang berada di Kota Samarinda.

Berdasarkan data-data dan perhitungan dari hasil penelitian responden atas kuesioner AHP tersebut, maka diperoleh hasil urutan prioritas berdasarkan prioritas tertinggi ditampilkan pada Gambar 1. Menurut hasil penilaian narasumber Pemerintah Daerah Kota Samarinda (BAPPEDA), dengan menggunakan metode AHP prioritas sasaran yang pertama ialah meningkatkan penyerapan tenaga kerja, dengan urutan prioritas kebijakannya yaitu penambahan panjang jalan, penambahan fasilitas jalan dan perbaikan jalan. Prioritas sasaran kedua ialah meningkatkan pertumbuhan ekonomi dengan urutan prioritas kebijakannya ialah penambahan fasilitas jalan, penambahan panjang jalan dan perbaikan jalan. Prioritas sasaran ketiga ialah mengurangi kemiskinan dengan urutan prioritas kebijakannya ialah penambahan panjang jalan, penambahan fasilitas jalan, dan perbaikan jalan.

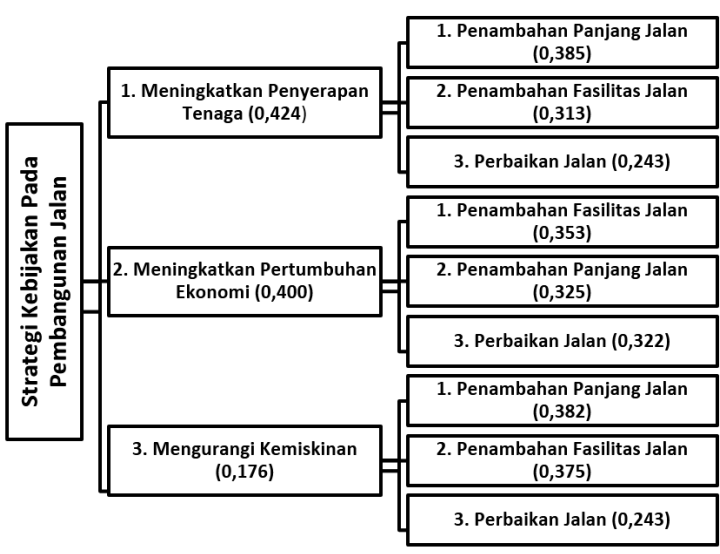

Gambar 4.1

Hasil Pengolahan AHP Menggunakan Expert Choise 2000

\section{Sasaran Meningkatkan Penyerapan Tenaga Kerja}

Sasaran meningkatkan penyerapan tenaga kerja maka yang menjadi prioritas pertama kebijakan yang harus dilakukan Pemerintah Daerah Kota Samarinda adalah penambahan panjang jalan. Dengan adanya penambahan panjang jalan pada daerahdaerah baru akan membuka peluang para investor untuk berinvestasi dan menanamkan modalnya di daerah tersebut berupa perluasan produksi. Secara tidak langsung hal tersebut dapat menyerap tenaga kerja sekitar daerah tersebut. Dengan melakukan cara tersebut diharapkan tingkat pengangguran di Kota Samarinda menurun setiap tahunnya.

\section{Sasaran meningkatkan pertumbuhan Ekonomi}

Dengan sasaran meningkatkan pertumbuhan ekonomi maka yang menjadi prioritas pertama kebijakan yang harus dilakukan Pemerintah Daerah Kota Samarinda adalah penambahan fasilitas jalan. Dengan adanya penambahan fasilitas jalan seperti drainase baik, rambu, marka, pengaman jalan dan jembatan timbang maka kondisi 
jalan menjadi baik tidak ada jalan berlubang, jalan menjadi teratur masyarakat pun menjadi nyaman, maka penambahan fasilitas jalan penting untuk meningkatkan pertumbuhan ekonomi karena dapat meningkatkan produktivitas masyarakat, tidak adanya kemacetan yang diakibatkan jalanan yang rusak dan rambu-rambu yang kurang.

Penambahan fasilitas jalan hampir sudah dilaksanakan di tiap daerah di Kota Samarinda. Namun, penambahan fasilitas berbeda-beda tiap daerah, contohnya di Kecamatan Samarinda Utara masih banyak jalanan yang berlubang yang diakibatkan karena buruknya sistem saluran air, dan hal tersebut sangat mengganggu produktivitas industri yang berada di kawasan tersebut seperti penyaluran barang yang lambat akibat kemacetan yang terjadi karena jalanan berlubang dan menyebabkan biaya produksi semakin tinggi diakibatkan peningkatan pemakaian bahan bakar.

\section{Sasaran Mengurangi Kemiskinan}

Dengan kondisi perekonomian yang cukup baik di Kota Samarinda masih mengalami masalah yaitu kemiskinan yang sebesar 36,6 ribu jiwa, walaupun turun setiap tahunnya. Masih banyak penduduk yang rentan terhadap masalah sosial dan berada di bawah garis kemiskinan karena belum banyak tersedianya lapangan pekerjaan yang memadai yang mengakibatkan masih tingginya angka pengangguran di Kota Samarinda, sekitar 8,57\%.

Jalan merupakan sarana penunjang transportasi memiliki peran penting khususnya transportasi darat. Dalam rangka mengurangi kemiskinan di Kota Samarinda, prioritas yang seharusnya dilakukan ialah dengan penambahan panjang jalan. Dengan penambahan panjang jalan di daerah-daerah miskin di Kota Samarinda dapat terbukanya daerah-daerah terisolasi, meningkatkan produktivitas ekonomi rakyat dan wilayah juga meningkatkan pendapatan masyarakat, mempermudah perhubungan antara pusat produksi dan pusat pemasaran, mendorong tumbuhnya kegiatan ekonomi di pedesaan, mempermudah lalu lintas barang dan jasa sehingga dapat mengurangi jumlah kemiskinan di Kota Samarinda.

\section{Simpulan dan Saran}

Berdasarkan hasil analisis yang dilakukan dalam hubungan pengaruh infrastruktur terhadap pertumbuhan ekonomi dan kebijakan pembangunan jalan di Kota Samarinda maka didapatkan hasil sebagai berikut:

Infrastruktur kesehatan berpengaruh signifikan terhadap pertumbuhan ekonomi kota Samarinda. Secara teoretis bahwa infrastuktur kesehatan berperan penting dalam meningkatkan pertumbuhan ekonomi. Semakin lengkap dan baik keberadaan infrastruktur kesehatan di Kota Samarinda akan meningkatkan pertumbuhan ekonomi.

Infrastruktur pelayanan air bersih berpengaruh signifikan terhadap pertumbuhan ekonomi Kota Samarinda. Secara teoretis infrastruktur pelayanan air bersih merupakan variabel yang berperan penting dalam meningkatkan pertumbuhan ekonomi,;semakin baik akses pemenuhan kebutuhan air bersih untuk masyarakat kota Samarinda, akan meningkat pula pertumbuhan ekonomi.

Infrastruktur jalan berpengaruh signifikan terhadap pertumbuhan ekonomi kota Samarinda. Secara teoretis bahwa infrastruktur jalan merupakan variabel yang berperan penting dalam meningkatkan pertumbuhan ekonomi. Semakin tinggi akses infrastruktur jalan memberi kelancaran terhadap mobilitas masyarakat dan arus barang, akan meningkatkan pertumbuhan ekonomi.

Dalam penetapan prioritas kebijakan pembangunan infrastruktur jalan di Kota Samarinda prioritas pertama yang harus dilakukan ialah meningkatkan penyerapan tenaga kerja melalui penambahan panjang jalan, prioritas kedua meningkatkan pertumbuhan ekonomi yaitu melalui; penambahan fasilitas jalan, dan prioritas ketiga mengurangi kemiskinan melalui penambahan panjang jalan.

Saran dalam tulisan ini, bahwa kebijakan pembangunan Kota Samarinda diarahkan pada pembangunan infrastruktur jalan, dan fasilitas pelayanan kesehatan (puskesmas), serta fasilitas pelayanan air bersih untuk meningkatkan pertumbuhan ekonomi Kota Samarinda.

\section{Daftar Pustaka}

Amrullah,Taufiq (2006). Analisis Pengaruh Pembangunan Infrastruktur Terhadap Pertumbuhan Ekonomi Indonesia.Tesis tidak dipublikasikan, Program MPKP 
Fakultas Ekonomi Universitas Indonesia. Depok.

Badan Perencanaan Pembangunan Nasional, (2003). Infrastruktur Indonesia Sebelum, Selama, dan Pasca Kritis. Perum Percetakan Negara RI, Jakarta.

Badan Pusat Statistik Kota Samarinda, (2013). Kota Samarinda Dalam Angka Tahun 2013.

Badan Pusat Statistik Kalimantan Timur, (2013). Kalimantan Timur Dalam Angka Tahun 2013.

Budiono, (1992). Teori Pertumbuhan Ekonomi, Seri Sinopsis Pengantar Ilmu Ekonomi No.4. BPFE, Yogyakarta.

Firdaus, M., (2004). Ekonometrika Suatu Pendekatan Aplikatif. Bumi Aksara, Jakarta

Gujarati,D.N,(2007). DasarEkonometrika Ed ke-3. Julius A Mulyadi (Penerjemah). Erlangga, Jakarta.

Jhingan,ML,(2000).Ekonomi Pembangunan dan Perencanaan, Rajawali Press, Jakarta.

Kian G., Kwik, (2002). Pembiayaan Pembangunan Infrastruktur dan Pemukiman.Bappenas, Jakarta.

Kamuli Sukarman, (2014), Evaluasi Tentang Implementasi Kebijakan Pengembangan Kawasan Minapolitan di Kabupaten Gorontalo Utara, MIMBAR, Vol. 30, No.1 (Juni,2014): 53-61.

Mankiw, N.Gregory, (2001). Principles of
Economics, (Alih bahasa: Aris Munandar), Erlangga, Jakarta.

Nuraliyah, (2011). Peran Pengembangan Infrastruktur dalam Pengentasan Kemiskinan di Indonesia: Jawa dan Luar Jawa [tesis]. Fakultas Ekonomi dan Manajemen. Institut Pertanian Bogor, Bogor.

Prasetyo R B., Firdaus M. (2009). Pengaruh Infrastruktur Pada Pertumbuhan Ekonomi Wilayah di Indonesia. Jurnal Ekonomi dan Kebijakan Pembangunan 2(2): 222-236.

Saaty, Thomas. L. (1993). Pengambilan Keputusan Bagi Para Pemimpin. Seri Manajemen No.134. PT Pustaka Binaman Pressindo, Jakarta.

Setiadi, Elen, (2006). Pengaruh Pembangunan Infrastruktur Dasar Terhadap Pertumbuhan Ekonomi Regional Indonesia (8 Provinsi di Sumatera). FEUI, Jakarta.

Stiglitz, Joseph. (2000). Economics of The Public Sector. $3^{\text {rd }}$ Edition. New York: W.W. Norton and Company.

Todaro,MP., dan Smith, SC., (2006). Pembangunan Ekonomi Ed ke-9. (Terjemahan) Erlangga, Jakarta.

World Bank,(1994). World Development Report: Infrastructure For Development. Oxford University Press, New York. 